\title{
New data on the morphology of Sphenothallus Hall: implications for its affinities
}

\author{
HEYO VAN ITEN, ROBT S. COX AND ROYAL H. MAPES
}

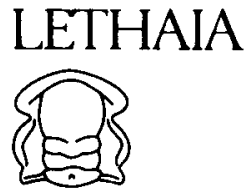

Van Iten, H., Cox, R. S. \& Mapes, R. H. 199204 15: New data on the morphology of Sphenothallus Hall: implications for its affinities. Lethaia, Vol. 25, pp. 135-144. Oslo. ISSN 0024-1164.

\begin{abstract}
Recent speculation on the phylogenetic relationships of Sphenothallus Hall, 1847 has focused on two alternatives: (1) affinity with hydrozoan or scyphozoan cnidarians, or (2) affinity with annelids or other 'worms'. We have found that some species of Sphenothallus formed branching clonal colonies, and that others produced a thin transverse wall, similar to the conulariid schott. Sphenothallus tests are composed of carbonate apatite and are built of numerous, extremely thin lamellae $(<1 \mu \mathrm{m})$ that parallel the surface of the test. The holdfast, long interpreted as consisting of a pair of nested cups, actually consists of a single closed, broadly conical expansion floored by a thin basal membrane. Many thecate hydrozoan and scyphozoan polyps form branching clonal colonies and produce a thin transverse wall, similar to that produced by Sphenothallus. Further, thecae of coronatid scyphozoans are built of submicron-thick lamellae that parallel the outer surface of the theca, and coronatid thecae possess a closed, broadly conical apical expansion that serves as a holdfast. No such combination of characteristics exists among annelids or other non-cnidarian taxa. The recent discovery of paired tentacles in Sphenothallus from the Early Devonian Hunsrück Slate by Fauchald et al., thought to indicate that Sphenothallus was wormlike, does not militate against a hypothesis of affinity with cnidarians. We therefore favour the hypothesis of a cnidarian affinity for Sphenothallus. $\square$ SPHENOTHALLUS, vermiform problematica, phylogenetic inference, coloniality, Cnidaria, Hydrozoa, Scyphozoa, Annelida, conulariids, byroniids, Bear Gulch Limestone.

Heyo Van Iten and Robt S. Cox, Museum of Paleontology, University of Michigan, Ann Arbor, Michigan 48109, USA; Royal H. Mapes, Department of Geological Sciences, Ohio University, Athens, Ohio 45701, USA; received 30th January, 1991, revised typescript accepted $27 \mathrm{th} \mathrm{J}_{\mathrm{h}} .{ }^{\cdot} 1991$.
\end{abstract}

Discussions of the phylogenetic affinities of the problematic fossil Sphenothallus Hall, 1847 have centered most recently on two alternative hypotheses. One of these is that Sphenothallus was either a hydrozoan (Price 1920a) or scyphozoan cnidarian (e.g. Kiderlen 1937; Bouček 1939; Moore \& Harrington 1956a, b; Bischoff 1978). Several proponents of this hypothesis also have argued for a close relationship to conulariids, a fossil group that has been widely interpreted as being allied with Scyphozoa (e.g. Kiderlen 1937; Moore \& Harrington 1956a, b; Werner 1966, 1967; Bischoff 1978; Van Iten 1991). The second hypothesis is that Sphenothallus was an annelid or other 'worm' (e.g. Wilson 1967; Mason \& Yochelson 1985; Feldmann et al. 1986).

The purpose of the present paper is to evaluate these alternative hypotheses through analysis of critical aspects of the anatomy of Sphenothallus and through comparisons with extant cnidarians and annelids. As will be discussed below, the few characteristics previously cited as linking Sphenothallus with annelids also are shared with hydrozoan and/or scyphozoan cnidarians, or are insufficiently detailed, and thus cannot provide a means for testing current alternative hypotheses. On the other hand, new information derived from analyses of gross skeletal anatomy and skeletal microstructure and mineralogy indicates that Sphenothallus is more similar to hydrozoans and scyphozoans than to any non-cnidarian group.

\section{Materials and methods}

Sphenothallus specimens directly examined for the present study were collected from the Bear Gulch Limestone member of the Heath Formation (Upper Mississippian, Namurian A; Cox 1986) near Lewistown, Montana, USA ('basinal facies' of Williams 1983), and from the East Mountain Formation (Pennsylvanian, Desmoinesian) near Fort Walter, Texas, USA (locality TXD-06; Boardman 1990).

Figured specimens are reposited in collections of the following institutions: the Department of Geology, State University of Iowa, Iowa City (SUI), USA; the Museum of Paleontology, University of Michigan, Ann Arbor (UMMP), USA; 
and the University of Montana Museum of Paleontology, Missoula ( ${ }^{*}$ UMMP), USA. Some of the specimens were examined with the aid of a Hitachi S-570 scanning electron microscope. Microstructural information was obtained from sectioned specimens polished with $0.3 \mu \mathrm{m}$ aluminum oxide powder. Such specimens were coated with carbon and examined using back-scattered electron imaging.

\section{General characteristics and occurrence}

Sphenothallus is characterized by an apatitic, finely lamellar test, generally about $1-10 \mathrm{~cm}$ long, which consists of an elongate tubule tapering very gradually to a small holdfast (Fig. 1). The tubule's wide, or apertural, end is open. The tubule is elliptical or subcircular in transverse cross-section and exhibits a pair of longitudinal thickenings that are situated at the end points of the tubule's widest diameter and extend its entire length. The thickenings are more or less crescentic in transverse cross-section (Schmidt \& Teichmüller 1956, 1958). Although the surface of the tubule has been described previously as smooth (Hall 1847; Mason \& Yochelson 1985), we observed low, rounded, closely spaced transverse ridges on specimens from the Collingwood Shale Formation (Upper Ordovician) of the Upper Peninsula of Michigan, USA (Cox \& Van Iten, unpublished).

Sphenothallus has been found in marine strata ranging in age from Early Ordovician to Permian (Choi 1990). It is known from numerous localities throughout the Northern Hemisphere (e.g. Ruedemann 1896a, b; Clarke 1913; Price 1920b; Howell 1949; Schmidt \& Teichmüller 1956, 1958; Hill 1978; Mason \& Yochelson 1985; Feldmann et al. 1986; Brood 1988; Choi 1990), and in the Southern Hemisphere has been recorded from Bolivia, Brazil and South Africa (e.g. Clarke 1913; Feldmann et al. 1986). Sphenothallus occurs most commonly in low-energy facies, usually dark shates and lime mudstones (e.g. Hall 1847; Price 1920 b; Ruedemann 1925), where it is often associated with abundant conulariids and other phosphatic fossils (e.g. Ruedemann 1896a; Hill 1978).

A variety of other Paleozoic tubular phosphatic fossils strongly resemble Sphenothallus including, among others, Byronia, Prestephanoscyphus and Phosphannulus (Kozłowski 1967;

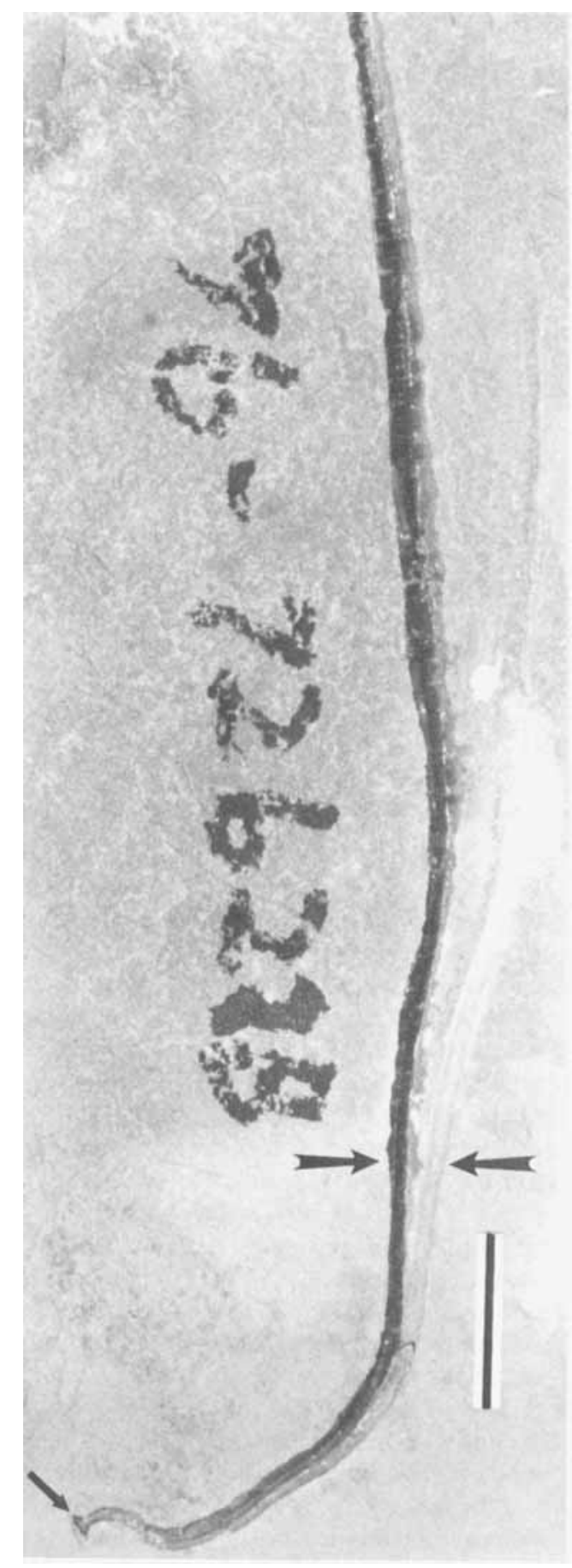

Fig. 1. Solitary Sphenothallus specimen from the Bear Gulch Member of the Heath Formation (Upper Mississippian, Namurian A) of central Montana. USA. Longitudinal thickenings indicated by large arrows, holdfast by small arrow. *UMMP 76-726228. Bar $=10 \mathrm{~mm}$. 
Müller et al. 1974; Bischoff 1989). These taxa are similar in gross morphology and general ecologic preferences, and in the possession of a finely lamellar, apatitic test. Sphenothallus, however, is unique in possessing paired longitudinal thickenings. Below, we will discuss the well-studied Byronia (Bischoff 1989) in the context of Sphenothallus affinities, but note here that a comprehensive, detailed study of all such forms is necessary before questions of relationships among them can be addressed properly.

\section{New data on Sphenothallus test morphology}

Microstructure and mineralogy. - Scanning electron microscopy (SEM) of polished sections reveals that Sphenothallus tests are composed of numerous, submicron-thick lamellae that parallel the surface of the test (Fig. 2). No other microstructural features (e.g. growth lines cross-cutting lamellae) were observed. SEM and X-ray diffraction analysis indicate that Sphenothallus tests are composed of cryptocrystalline carbonate apatite and are mineralogically similar to conulariid tests (Cox \& Van Iten, unpublished). Characteristic thickening of the tubule at the two end points of its widest diameter is due to gradual expansion of individual lamellae. Owing to incomplete preservation of available material, we were unable to examine the apertural area in detail; however, it appears from natural molds of Sphenothallus that the longitudinal thickenings taper slightly toward the aperture.

Multiple clonal branching. - Clarke (1913) and Price (1920b) previously reported the existence of a specimen of Sphenothallus that branches; however, this occurrence has not entered subsequent discussions of the taxon. The specimen in question was collected from the Ponta Grossa Shales (Devonian) near Ponta Grossa, Brazil, and was referred by Clarke to Serpulites sica Salter. The specimen consists of a single parent tubule with a number of daughter tubules arranged in a regular array along its sides (Fig. 3). Like non-branching Sphenothallus, parent and daughter tubules of $S$. sica (Salter) are gently tapered, exhibit an elliptical transverse cross-section, and possess a pair of longitudinal thickenings situated $180^{\circ}$ apart from one another (Clarke 1913). The parent tubule's

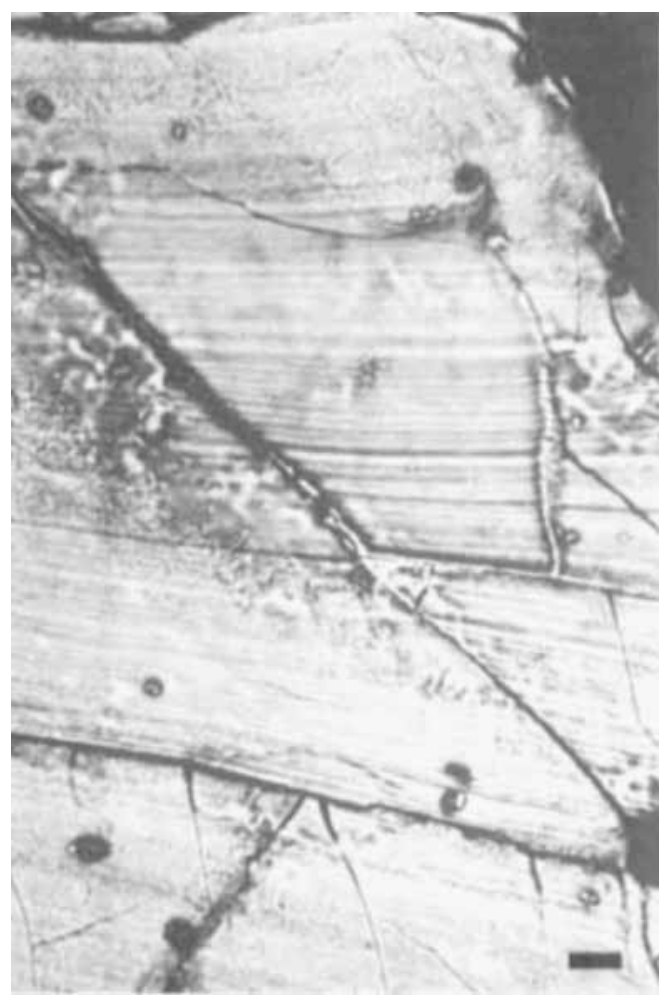

Fig. 2. Scanring electron micrograph (back-scattered electron mode) of a longitudinal section through a Sphenothallus holdfast, showing the fine lamellae. Specimen from the Bear Gulch Member of the Heath Formation (Upper Mississippian, Namurian A) of central Montana. UMMP 65402. Bar $=10 \mu \mathrm{m}$.

basalmost portion is missing; however, by analogy with other Sphenothallus specimens it probably terminated in an attachment disc. Clarke (1913) states that $S$. sica tests are chitinous, but he makes the same claim for Sphenothallus specimens (e.g. specimens from the Trenton Group (Middle Ordovician) of New York, USA) that we have determined to be apatitic. Although we lack conclusive evidence, we suspect that $S$. sica tests are also apatitic.

Unlike most other known Sphenothallus tubules (e.g. Fig. 1), daughter tubules of the branching $S$. sica do not possess an attachment disc. Rather, their apical ends are confluent with the side of the parent tubule (Fig. 3B, C). This indicates that the daughter tubules are not attached epizoically to the parent, as is the case in other previously documented cases of tubule clusters (e.g. Moore \& Harrington 1956a: fig. 28), but are continuous with it. 

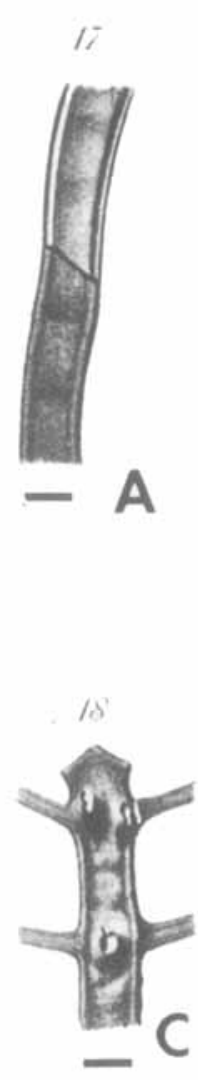

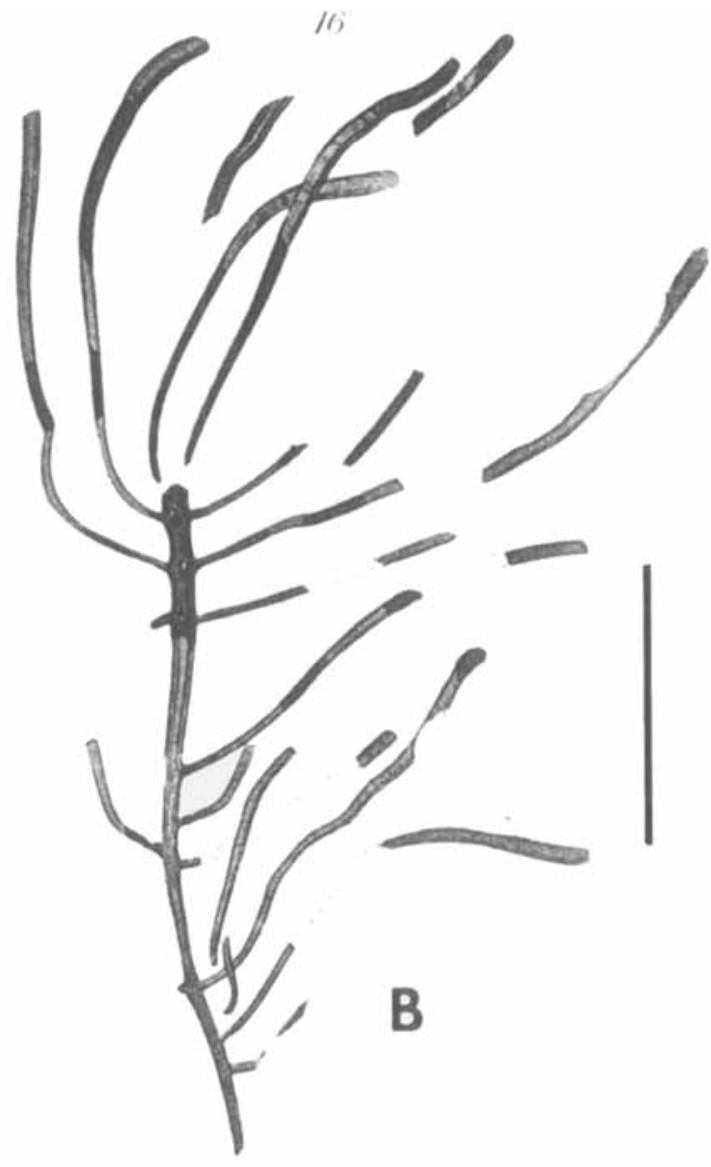

Fig. 3. Branching

Sphenothallus sica (Salter) specimen from the Ponta Grossa Shale (Devonian), near Ponta Grossa, Brazil. The present location of this specimen is unknown. Figure reproduced from Clarke (1913: figs. 16-18). $\square$ A. Portion of one of the tubules,

highlighting the longitudinal thickenings. Bar $=1 \mathrm{~mm}$. $\square$ B. View of the entire specimen. Bar $=16 \mathrm{~mm}$. $\square$ C. Detail of several daughter tubules, highlighting confluence of their apical ends with the side of the parent. Bar $=1 \mathrm{~mm}$.
As suggested by Clarke (1913) and Price (1920a), the anatomy of the branching $S$. sica is interpreted most easily as indicating a clonal relationship between daughter tubules and the single parent tubule. The regular arrangement of daughter tubules along the parent, together with abrupt bending of the daughters toward the parent tubule's aperture (Fig. 3B), suggest that the Brazilian specimen represents a clonal colony, with daughter tubules connected to the parent throughout life.

Additional evidence of clonal budding is provided by a group of about 10 Sphenothallus tubules from the Bear Gulch Limestone (Fig. 4). As in the case of the branching $S$. sica, none of the tubules in the Bear Gulch specimen possesses a basal disc, and the apical ends of daughter tubules merge smoothly with the sides of their parents. Unlike $S$. sica, though, daughters in the Bear Gulch specimen are themselves observed to branch. While contacts between most of the Bear Gulch tubules have been obscured by weathering, part of the contact between two of them is well preserved. As shown in Fig. 4B, the basal part of the daughter tubule runs along the inner surface of the parent, over a distance of at least $10 \mathrm{~mm}$. Just above the site where the daughter tubule detaches from the parent, the daughter narrows (over a distance of about $1 \mathrm{~mm}$ ) to about twothirds of its width below this point, and then widens again.

These characteristics rule out interpretation of this occurrence as being due to displacement of parts of a single tubule that was broken. Together with the absence of an attachment disc, the fact that the basal part of the daughter tubule is in continuous contact with the inner surface of the parent tubule, over a distance of at least $10 \mathrm{~mm}$, also rules out epizoic settlement. Although most of the parent tubule is not preserved 

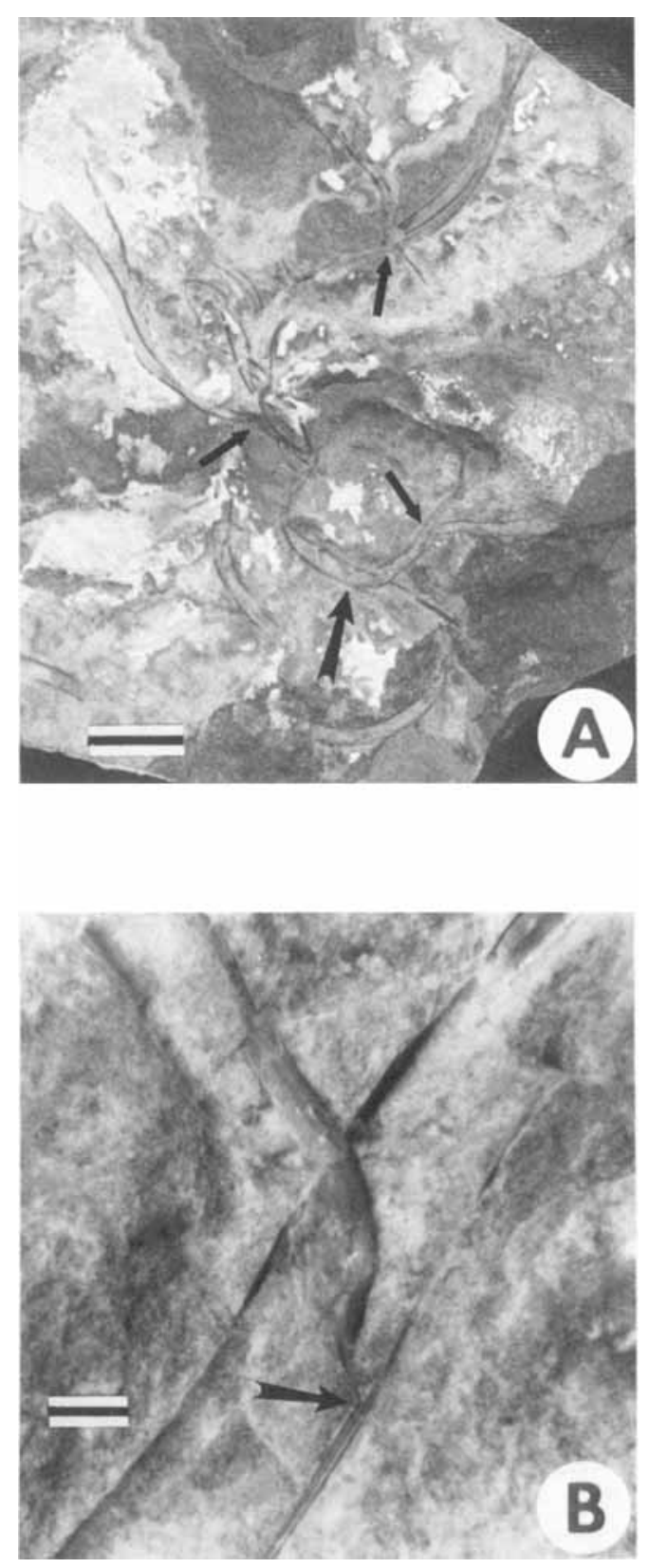

Fig. 4. Branching Sphenothallus specimen from the Bear Gulch Member of the Heath Formation (Upper Mississippian, Namurian A) of central Montana, USA. *UMMP 6463. $\square$ A. View of the entire colony. Arrows indicate selected branch sites. Bar $=10 \mathrm{~mm}$. $\square$ B. Detail of the branch site discussed in the text and indicated by the large arrow in Fig. $4 \mathrm{~A}$, showing contact of the outer surface of the daughter tubule with the inner surface of the parent (arrow). The arrow is situated at the point where the daughter tubule diverges from the parent tubule. Bar $=1 \mathrm{~mm}$. in the parent/daughter contact zone, the daughter tubule must have perforated the parent. We therefore suggest that this species of Sphenothallus was capable of perforate budding.

Schotts. - Approximately 30 incomplete Sphenothallus specimens (SUI 63438) collected from the East Mountain Formation near Fort Walter, Texas, were found to terminate adapically in a thin, outwardly convex transverse wall (Figs. 5, 6). This structure is essentially identical in form and microstructure to the conulariid schott (Van Iten 1991), and for this reason we will refer to it as a schott.

Both conulariid and Sphenothallus schotts are apatitic, finely lamellar structures resembling a blunt-ended cone (Fig. 5). The apical, closed end of the cone forms a transverse, diaphragm-like covering at or near the broken end of the tubule, and the sides of the cone extend along the inner surface of the tubule proper, toward the aperture. Although all of the specimens from the East Mountain Formation are broken below the aperture, inspection of sectioned specimens (Fig. 5) suggests that the schott extended all the way to the aperture. The line of "contact between the transverse portion of the schott and the tubule proper is often irregular, and the topography of

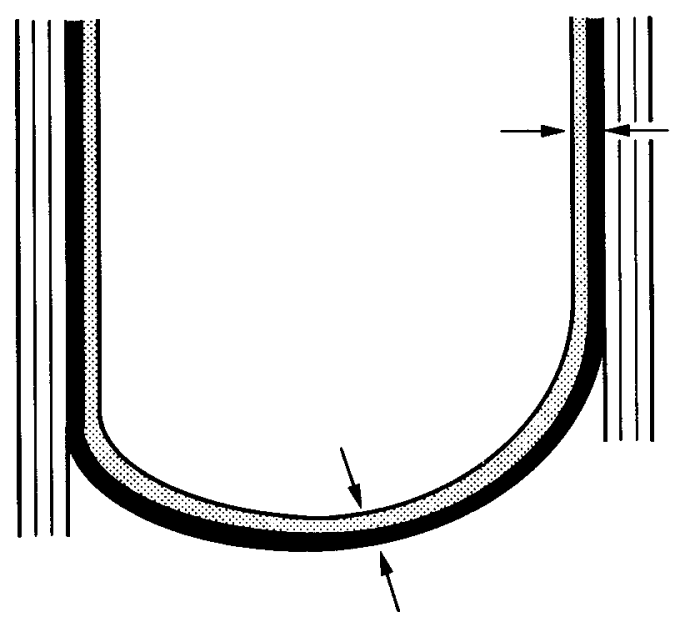

Fig. 5. Schematic longitudinal section through a schott-bearing Sphenothallus specimen, showing selected test lamellae. The section passes through the longitudinal thickenings. The schott is that part of the test highlighted by the arrows and shading. $\mathrm{Bar}=1 \mathrm{~mm}$. 


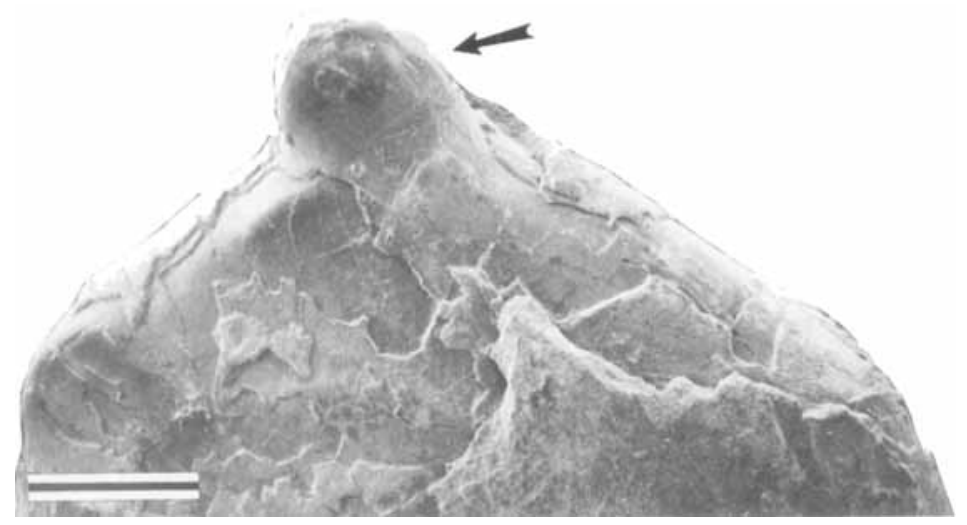

Fig. 6. External view (SEM) of a Sphenothallus schott exhibiting a prominent, knob-like central protuberance (arrow). A similar protuberance commonly occurs on conulariid schotts (see for example Bouček 1939: fig. 3b). SUI 63438a. Bar $=1 \mathrm{~mm}$.

the schott varies between specimens. Also, some schotts exhibit a subcentrally located, imperforate, knob-like protuberance (Fig. 6), a feature commonly present on conulariid schotts (Bouček 1939; Sinclair 1948).

The occurrence of schotts in Sphenothallus provides compelling evidence that test-producing soft tissues were present on the inner surface of the test. The simplest and intuitively most satisfactory explanation of schott formation, suggested by analogy with schott-like structures produced by extant coronatid scyphozoans (Chapman \& Werner 1972), is that they grew by centripetal accretion of whole lamellae. The lamellae in Sphenothallus schotts are identical in structure and arrangement to lamellae in other parts of the test, suggesting that growth of all parts of the test occurred through centripetal accretion.

Although the cause of schott formation in Sphenothallus currently remains uncertain, one possible explanation is suggested by comparisons with conulariids (Van Iten 1991) and extant thecate coronatid scyphozoans (Chapman \& Werner 1972). In coronatids, schott formation has been shown to occur in response to severance of the tubule, with the schott forming a covering over the exposed end of the test, and the same mechanism is thought by some authors (Werner 1967; Bischoff 1978; Van Iten 1987, 1991) to account for the occurrence of schotts in conulariids.

Anatomy of the holdfast. - The anatomy of the Sphenothallus holdfast was first discussed in detail by Ruedemann (1896a, b), who interpreted this structure as consisting of an inverted cup within a second inverted cup, with a closed tubule [the apex of the tubule proper] connecting both and a thin membrane joining the inverted rims of the cups' (Bodenbender et al. 1989: p. 220, fig. 2A). This interpretation, accepted as accurate by several subsequent authors (e.g. Moore \& Harrington 1956a), was questioned recently by Bodenbender et al. (1989). Examination of Sphenothallus specimens from the Bear Gulch Limestone confirms that Ruedemann's interpretation is inaccurate, and corroborates the alternative reconstruction offered by Bodenbender et al. (1989: fig. 2B). Inspection of the Bear Gulch material (Fig. 7) reveals that the holdfast consists of a single thick, broadly conical expansion with a thin, flat, subcircular basal membrane (Fig. 7B). The space within the inverted cup communicates with the cavity of the tubule, and a second, internal inverted cup is not present. Inspection of sectioned specimens using SEM reveals that the holdfast and tubule proper form a single, continuously laminated structure (Fig. 8). The basal membrane, the part of the holdfast in direct contact with the substratum (in the Bear Gulch Limestone, usually a nautiloid shell or another Sphenothallus tubule), is less than $10 \mu \mathrm{m}$ thick. On tubules that have been detached from their substrate, preservation of the basal membrane was not observed, apparently owing to breakage of this delicate structure. There are, however, numerous occurrences of isolated basal membranes attached to nautiloid shells or other hard substrata, or occasionally, of membranes that include material from the apicalmost portion of the cup-like part of the holdfast. The identity of the isolated basal membranes as parts of Sphenothallus holdfasts is confirmed by association with partial tubules tapering toward membranes. 

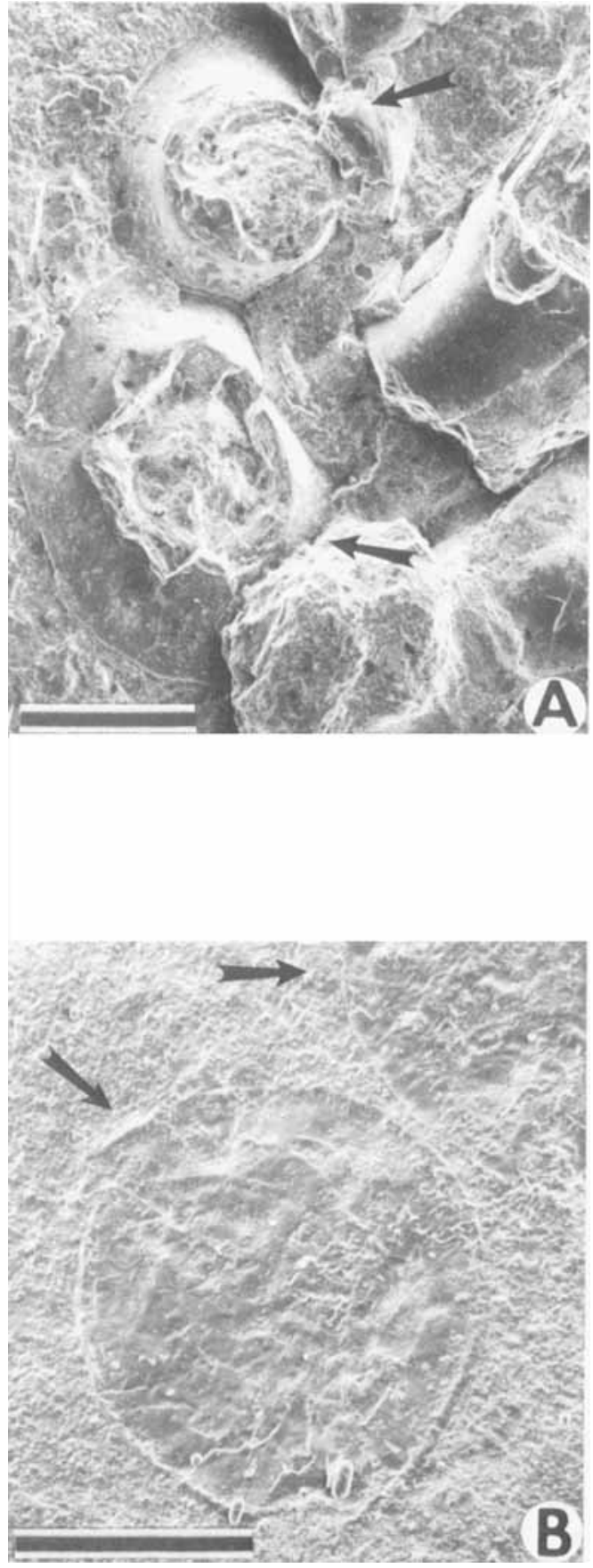

Fig. 7. Scanning electron micrographs of Sphenothallus holdfasts from the Bear Gulch Member of the Heath Formation (Upper Mississippian, Namurian A) of central Montana, USA. $\square$ A. View of the upper part of two broken holdfasts (arrows). *UMMP 76-7262lB. Bar $=1 \mathrm{~mm}$. $\square$ B. View of the inner surface of isolated basal membranes (arrows) of two other holdfasts. *UMMP 76-70801 B3. Bar $=1 \mathrm{~mm}$.

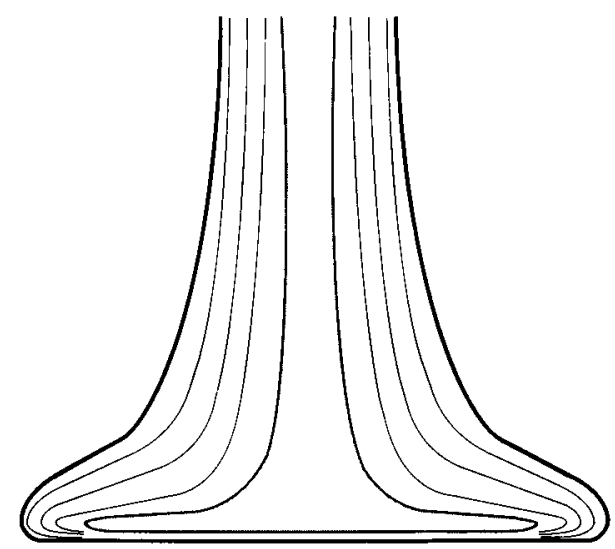

Fig. 8. Schematic longitudinal section through a Sphenothallus holdfast, showing selected test lamellae. The figure is a composite based on information obtained from several incomplete holdfasts. Bar $=1 \mathrm{~mm}$.

\section{Comparisons}

As noted above in the introductory section, Sphenothallus has been interpreted most recently as a hydrozoan or scyphozoan cnidarian, or as an annelid. We compared Sphenothallus with specimens and published descriptions (e.g. Jollie 1962; Jones 1985; Barnes 1987) of other metazoan phyla, and we found no evidence to suggest that Sphenothallus is related more closely to any organism other than annelids or cnidarians. For this reason, the rest of this discussion focuses on comparisons with members of these two phyla.

Annelids. - The most extensive previous discussion of the hypothesis of an annelid affinity for Sphenothallus is that of Fauchald et al. (1986), who documented relic soft parts in five specimens from the Hunsrück Slate (Lower Devonian) of Germany. The soft parts extend from the apertural end of the tubules and consist of what Fauchald et al. (1986) interpreted as a pair of tentacles and a short, spool-shaped tissue mass uniting the tentacles at their base. Neither the tentacles nor the spool-shaped tissue mass show evidence of segmentation (Fauchald et al. 1986).

In addition to possessing a pair of tentacles and a spool-shaped tissue mass, two Hunsrück 
specimens (WS 515a and b, Bavarian State Museum, Munich) purportedly also exhibit 'internal structure' that 'appears to indicate' that the tentacles 'were held up by a sleeve of supportive tissue' (Fauchald et al. 1986:62). The nature and location of this internal structure are not specified.

Although Fauchald et al. (1986:64) did not ally Sphenothallus with any particular extant group, they did state that the presence of paired tentacles 'would seem to prove beyond question that Sphenothallus was indeed wormlike.' Fauchald et al. (1986) also suggested that the sleeve of tissue that purportedly supported the two tentacles is similar to the supportive structure at the base of the tentacular crown of extant sabellid polychaetes. In a subsequent article, however, Fauchald and Yochelson (1990:22) stated that Sphenothallus was not an annelid, based on the "lack of segmentation in its ... soft parts.'

Hydrozoan and scyphozoan cnidarians. - Sphenothallus is similar also to hydrozoan and scyphozoan polyps. For example, polyps of the scyphozoan order Coronatida are sheathed in a steeply conical, chitinous theca that consists of an elongate tubule terminating adapically in a minute, closed attachment disc (e.g. Chapman \& Werner 1972). Although non-mineralized, coronatid thecae are built of numerous, submicronthick lamellae that generally parallel the surface of the theca. Just as lamellae in Sphenothallus tubules gradually expand to form a pair of longitudinal thickenings, thecae of some coronatids exhibit symmetrically arrayed, internal longitudinal ridges, produced by localized inflection of inner thecal lamellae. Like the Sphenothallus holdfast, the holdfast of coronatid thecae consists of a single broadly conical expansion with an extremely thin, flat base.

Also like Sphenothallus, coronatids (and thecate hydrozoan polyps) can be either solitary or colonial (e.g. Werner 1970, 1979). Some colonial coronatids exhibit a branching architecture similar to that of colonial Sphenothallus (Figs. 3, 4). For example, the branching pattern exhibited by the Bear Gulch Sphenothallus specimen (Fig. 4) bears a striking resemblance to that of the coronatid Stephanoscyphus mirabilis illustrated by Werner (1970: fig. 2A, B).

As noted above, coronatid polyps that have been severed often cover exposed soft tissues by producing a thin, multilamellar patch of smooth thecal material that extends along the inner surface of the theca toward the aperture. This feature is thus similar in form and microstructure to conulariid and Sphenothallus schotts.

Similarities in soft-part anatomy also are evident. Like Sphenothallus, early developmental stages of many hydrozoan and scyphozoan polyps (e.g. the hydrozoan Gonionemus vindobonensis and the scyphozoans Haliclystus octoradiatus and Tripedalia cystophora) exhibit only two tentacles, situated $180^{\circ}$ apart from one another (Salvini-Plawen 1978). In many polyps, the centrally located mouth opening is situated atop a prominent, mound-like manubrium (e.g. Hyman 1940), similar in form and location to the spoolshaped tissue mass in exceptionally preserved Hunsrück Sphenothallus. While hydrozoan and scyphozoan polyps generally are more or less circular in transverse cross-section, rather than elliptical, transverse cross-sections through larval hydrozoan and scyphozoan polyps (more precisely, attached planula larvae in the initial stages of transformation into a polyp) are elliptical (e.g. Hyman 1940).

Finally, Sphenothallus is similar to other fossil taxa that show evidence of affinity with coronatid scyphozoans. For example, the Byroniida (Bischoff 1989) possess an apatitic, multilamellar test that is essentially identical in microstructure, gross anatomy, mode of growth, and damage repair to the coronatid theca, and is very similar to the test of Sphenothallus. A conspicuous difference between byroniid and Sphenothallus tests is the presence of whorls of tetramerally arranged, thorn- or knob-like apophyses on the inner surface of the test in the byroniid 'family' Prestephanoscyphidae. Such apophyses are also present in the theca of some coronatid scyphozoans (e.g. Chapman \& Werner 1972).

\section{Discussion}

The foregoing comparisons show that characteristics thought to indicate affinity with annelids (e.g. presence of two tentacles) are also shared by Sphenothallus and hydrozoan and/or scyphozoan cnidarians. Sphenothallus exhibits features that apparently are not found among known annelids (as indicated by review of the annelid literature and examination of preserved specimens in collections of the University of Michigan), but 
which are present among hydrozoan and/or scyphozoan cnidarians. These include: (1) possession of a multilamellar theca with a closed, broadly conical holdfast; (2) production of schotts; (3) formation of erect, regularly branching clonal colonies. Interestingly, the first two features and, possibly, all three are shared also with conulariids (Cox and Van Iten, unpublished).

These observations suggest that the hypothesis of a hydrozoan or scyphozoan affinity for Sphenothallus is more probable than the alternative hypothesis of affinity with annelids. In addition, similarities between Sphenothallus and conulariids suggest that these two groups also are closely related. Opponents of these interpretations (Termier \& Termier 1949, 1953; Kozłowski 1968; Babcock 1991) have cited the absence of phosphatic mineralization in thecae of hydrozoans and scyphozoans as evidence against a cnidarian affinity for Sphenothallus (and conulariids); however, the detailed similarities discussed above suggest that Sphenothallus can be interpreted as a kind of cnidarian that differed from others in this character. Analogously, no one would argue that milleporine or stylasterine hydrozoans are not cnidarians because they produce skeletons composed of calcium carbonate and other hydrozoans do not, or that anthozoans should be excluded from Cnidaria because they display a biradian ('bilateral'), rather than perfectly radial, pattern of symmetry. We therefore propose that Sphenothallus was a biradial, solitary or colonial polyp that differed from thecate polyps of extant hydrozoan and scyphozoan cnidarians in exhibiting thecal mineralization and in having two tentacles and a laterally compressed calyx throughout life.

Acknowledgements. - We thank Ellis L. Yochelson for allowing us to examine original radiographs of pyritized Sphenothallus specimens from the Hunsrück Slate. We also thank Tatiana Van Iten for printing the photographs, and Brian E. Bodenbender and R. G. M. MacLeod for reading the manuscript. Stefan Bengtson reviewed the manuscript and suggested several important revisions. Permission to borrow museum specimens was granted by William G. Melton (University of Montana, Missoula). This study was funded in part by the Department of Geological Sciences, University of Michigan, Ann Arbor, and by NSF Grant BNS-8521097 to Daniel C. Fisher. Support for this research also was provided by Petroleum Research Fund Grants 15821-AC2 and No. 20742-B8-C to Royal H. Mapes. The scanning electron microscope used in this work was acquired under NSF Grant BSR83-14092 to the Department of Geological Sciences, University of Michigan.

\section{References}

Babcock, L. E. 1991: The enigma of conulariid affinities. In Simonetta, A. M. \& Conway Morris, S. (eds.): The Early Evolution of Metazoa and the Significance of Problematic Taxa, 133-143. Cambridge University Press, Cambridge.

Barnes, R. D. 1987: Invertebrate Zoology, 5th Edn, 893 pp. Saunders College Publishing, Philadelphia.

Bischoff, G. C. O. 1978: Internal structures of conulariid tests and their functional significance, with special reference to Circoconulariina n. suborder (Cnidaria, Scyphozoa). Senckenbergiana Lethaea 59, 275-327.

Bischoff, G. C. O. 1989; Byroniida new order from early Palaeozoic strata of eastern Australia (Cnidaria, thecate scyphopolyps). Senckenbergiana Lethaea 69, 467-521.

[Boardman, D. R. 1990: Biostratigraphy of middle and late Pennsylvanian (Desmoinesian-Virgilian) ammonoids. 247 pp. Unpublished PhD dissertation. Texas Technical University, Lubbock.]

Bodenbender, B. E., Wilson, M. A. \& Palmer, T. J. 1989: Paleoecology of Sphenothallus on an Upper Ordovician hardground. Lethaia 22, 217-225.

Bouček, B. 1939: Conulariida. In Schindewolf, O. H. (ed.): Handbuch der Paläozoologie, Band 2A, A113-A131. Gebrüder Bornträger, Berlin.

Brood, K. 1988: A new species of Campylites from Gotland. Geologiska Föreningens i Stockholm Förhandlingar 110, 8385.

Chapman, D. M. \& Werner, B. 1972: Structure of a solitary and colonial species of Stephanoscyphus (Scyphozoa, Coronata) with observations on periderm repair. Helgoländer Meeresuntersuchungen 23, 393-421.

Choi, D. K. 1990: Sphenothallus ('Vermes') from the Tremadocian Dumugol Formation, Korea. Journal of Paleontology 64, 403-408.

Clarke, J. M. 1913: Fosseis devonianos do Paraná. Brazil, Serviço Geologico e Mineralogico, Monographias, Volume 1, $353 \mathrm{pp}$.

Cox, R. S. 1986: Preliminary report on the age and palynology of the Bear Gulch Limestone (Mississippian, Montana). Journal of Paleontology 60, 952-956.

Fauchald, K. \& Yochelson, E. L. 1990: A tubiculous animal from the Hunsrück Slate (Lower Devonian, Southern Germany). Paläontologische Zeitschrift 64, 15-23.

Fauchald, K., Stürmer, W. Yochelson, E. L. 1986: Sphenothallus 'Vermes' in the Early Devonian Hunsrück Slate, West Germany. Paläontologische Zeitshrift 60, 57-64.

Feldmann, R. M., Hannibal, J. T. \& Babcock, L. E. 1986: Fossil worms from the Devonian of North America (Sphenothallus) and Burma ('Vermes') previously identified as phyllocarid arthropods. Journal of Paleontology 60, 341346.

Hall, J. 1847: Palaeontology of New York: Volume I, Containing Descriptions of the Organic Remains of the Lower Division of the New York System, 339 pp. C. Van Benthuysen, Albany.

[Hill, V. 1978: Sphenothallus cf. S. angustifolius from the Mississippian Bear Gulch Limestone of central Montana. 28 pp. Unpublished undergraduate thesis, Princeton University, Princeton, NJ.]

Howell, B. F. 1949: New hydrozoan and brachiopod and new genus of worms from the Ordovician Schenectady Formation of New York. Bulletin of the Wagner Free Institute of Science 24, 1-8. 
Hyman, L. 1940: The Incertebrates: Promsod Through Ctenophora, Volume 1, 696 pp. McGraw-Hill, New York

Jollie, M. 1962: Chordate Morpholog,y, 478 pp. Reinhold, New York.

Jones, M. L. 1985: On the Vestimentifera, a new phylum: six new species, and other taxa from hydrothermal vents and elsewhere. Bulletin of the Biological Society of Washington 6, $117-158$.

Kiderlen, H. 1937: Die Conularien. Uber Bau and Leben der ersten Scyphozoa. Neues Jahrbuch für Mineralogie, BeilageBand 77, 113-169.

Kozlowski, R. 1967: Sur certaines fossiles ordoviciens à test organique. Acta Palaeontologica Polonica 12, 99-132.

Kozłowski, R. 1968: Nouvelles observations sur les conulaires. Acia Palaeontologica Polonica 13, 497-531.

Mason, C. \& Yochelson, E. L. 1985: Some tubular fossils (Sphenothallus: 'Vermes') from the Middle and Late Paleozoic of the United States. Journal of Paleontology 59, 85-95.

Moore, R. C. \& Harrington, H. J. 1956a: Scyphozoa. In Moore, R. C. (ed.): Treatise on Invertebrate Paleontology, PF, Coelenterata, F27-F38. Geological Society of America and University of Kansas Press.

Moore, R. C. \& Harrington, H. J. 1956b: Conulata. In Moore, R. C. (ed.): Treatise on Invertebrate Paleontology, PF, Coelenterata, F54-F66. Geological Society of America and University of Kansas Press.

Müller, K. J., Nogami, Y. \& Lenz, H. 1974: Phosphatische Ringe als Microfossilien im Altpaläozoikum. Palaeonto. graphica A 146, 79-99.

Price, W. A. 1920a: Hydrozoan affinities of Serpulites Sowerby (abstr.). Bulletin of the Geological Society of America 31, $210-211$

Price, W. A. 1920b: Notes on the paleontology of Webster County. Invertebrate fossils from the Pottsville Series. In Reger, D. B. (ed.): West Virginia Geological Survey County Reports, Webster County, 544-620.

Ruedemann, R. H. 1896a: Note on the discovery of a sessile Conularia - article I. American Geologist 17, 158-165.

Ruedemann, R. H. 1896b: Note on the discovery of a sessile Conularia - article II. American Geologist 18, 65-71.

Ruedemann, R. H. 1925: The Utica and Lorraine Formations of New York, P2. Systematic Paleontology. No. 1. Plants, Sponges, Corals, Graptolites, Crinoids, Worms, Bryozoans, Brachiopods. New' York State Museum Bulletin 262, $171 \mathrm{pp}$.

Salvini-Plawen, L. 1978: On the origin and evolution of the lower Metazoa. Zeitschrift für Zoologische Systematik und Evolutionsforschung 16, 40-88.

Schmidt, W. \& Teichmüller, M. 1956: Die Enträtselung eines bislang unbekannten Fossils im Deutschen Oberkarbon, Sphenothallus stubblefieldi n. sp., und die Art seines Auftretens. Geologisches Jahrbuch 71, 243-298.

Schmidt, W. \& Teichmüller, M. 1958: Neue Funde von Sphenothallus auf dem westeuropäischen Festland, ins besondere in Belgien, und ergänzende Beobachtungen zur Gattung Sphenothallus. Association pour lètude de la Paléontologie et de Stratigraphie Houillères, Publication 33, 34 pp.

[Sinclair, G. W. 1948: The biology of the Conularida. $428 \mathrm{pp}$. Unpublished PhD dissertation, MacGill University, Montréal.]

Termier, H. \& Termier, G. 1949: Position systématique et biologie des Conulaires. Revue Scientifique 86, 711-722.

Termier, H. \& Termier, G. 1953: Les conularides. In Piveteau, J. (ed.): Traité de Paléontologie. Tome III. Onychophores, Arthropodes, Echinodermes, Stomocordés, 1006-1013. Masson \& Cie, Paris.

Van Iten, H. 1987: Mode of life of the Conulariida and its implications for conulariid affinities. Geological Society of America, Abstracts with Programs 19, No. 7, 876.

Van Iten, H. 1991: Evolutionary affinities of conulariids. In Simonetta, A. M. \& Conway Morris, S. (eds.): The Early Evolution of Metazoa and the Significance of Problematic Taxa, 145-155. Cambridge University Press, Cambridge.

Van Iten, H. 1991: Anatomy, patterns of occurrence, and nature of the conulariid schott. Palaeontology 34, 939-954.

Werner, B. 1966: Stephanoscyphus (Scyphozoa, Coronatae) und seine direkte Abstammung von den fossilen Conulata. Helgoländer Wissenschaftliche Meeresuntersuchungen 13, 317-347.

Werner, B. 1967: Stephanoscyphus Allman (Scyphozoa, Coronatae), ein rezenter Vertreter der Conulata? Paläontologische Zeitschrift 4I, 137-153.

Werner, B. 1970: Contribution to the evolution in the genus Stephanoscyphus (Scyphozoa Coronatae) and ecology and regeneration qualities of Stephanoscyphus racemosus Komai. Publications of the Seto Marine Biological Laboratory 18, $1-20$.

Werner, B. 1979: Coloniality in the Scyphozoa: Cnidaria In Larwood, G. \& Rosen, B. R. (eds.): Biology and Systematics of Colonial Organisms, 81-103. Academic Press, London.

Williams, L. A. 1983: Deposition of the Bear Gulch Limestone: a carboniferous Plattenkalk from central Montana. Sedimentology 30, 843-860.

Wilson, R. B. 1967: A study of some Namurian marine faunas of central Scotland. Royal Society of Edinburgh Transactions $66,445-486$ 